\title{
Developing an Integrated Cattle Farm on Ex-coal Mining Area
}

\author{
Tedi Yunanto ${ }^{1}$, Farisatul Amanah ${ }^{2}$, Doddy Herika ${ }^{3}$ \\ ${ }^{1}$ Bandung Polytechnic of Energy and Mining, Ministry of Energy and Mineral Resources \\ Jl. Jend. Sudirman No. 623 Bandung, Indonesia 40211 \\ tedi.yunanto@esdm.go.id \\ ${ }^{2}$ Directorate General Mineral and Coal, Ministry of Energy and Mineral Resources \\ Jl. Prof. Dr. Soepomo, SH No.10, Jakarta, Indonesia \\ farisatul.amanah@esdm.go.id \\ ${ }^{3} \mathrm{PT}$ Berau Coal \\ Jl. HR Rasuna Said Kav 1-2 Blok X-1, Jakarta, Indonesia \\ doddy.herika@beraucoal.co.id
}

\begin{abstract}
Mining companies are required to carry out reclamation process. Reclamation on ex-coal mining area has an opportunity to be functioned as Integrated Cattle Farm (ICF) as it is stated in Good Mining Practice Implementation Guidelines in Indonesia. The ICF aims to elaborate surrounding community development projects and empower domestic cattle beef. In addition, beef import is still conducted to meet domestic beef demand. However, some strategies have been arranged including extended livestock area project. As a preliminary study, this project aims to review the possibility of cattle farm development on ex-mining area from the weight increment and birth rate of cattle. The data was taken from PT Berau Coal, East Kalimantan Province, Indonesia and analysed using descriptive statistics. The results showed that the birth rates are: Brahman cross cattle (65\%); Bali cattle (42\%); and Donggala cattle (94\%). Based on the farming system, the highest mean of Brahman cross cattle weight gain on the intensive farming (zero grazing) was $0.43 \mathrm{~kg} / \mathrm{day}$ and $0.22 \mathrm{~kg} /$ day on the semi-intensive farming (grazing). To prepare ICF as community livelihood in the mine closure, some strategies need to be applied due to weight gain improvement. For commercial purposes of beef cattle, male cattle are better selected than female cattle. This project however improves capability and independency of the community from the training program. Moreover, ICF can be endorsed as sustainability of natural resources management from coal mine closure.
\end{abstract}

Keywords: cattle, integrated farming, reclamation, mine closure

\section{Introduction}

Mine closure is final steps of land rehabilitation and community development programs which sustainability is the key of success [5]. In addition, mine closure requires collaboration of ideas, abilities and skills to be developed in the research and development [10]. Therefore, Mine Reclamation and Mine Closure Guidelines in Indonesia allows mine permit holder to elaborate the program besides re-vegetation program such as building housings, tourism object, water intake facility and livestock or farming. Livestock and farming are more selected in order to promote sustainable development alternatives for surrounding community.

However, Indonesia presently still imports beef to supply 26\% of domestic demand in 2010-2014 [11]. Livestock on ex-coal mining area can be endorsed as government supporting project as was arranged to extend breeding area to gain cattle population and avoid productive cows cutting [14]. This project is expected to contribute beef production to meet the demand in the future, as well as income source, especially for local community.

In order to define the opportunity, preliminary study started to calculate the project feasibility. First, ex-coal mining area has different soil fertility due to the blending and placement process during soil stripping [3]. Besides, soil contamination has been an issue to grow the plants as forage. In mineral mines such as tin mine, bioaccumulation is occurred in the re-vegetation plants in high concentration level [13]. Although coal exploitation applies minimum chemical reagent, the research has to involve this issue to proof. Second, landscape alteration during open-pit mining exploitation may affect deforestation since many coal permit holders are located in Kalimantan (forestry area). It causes forest interior and ecological change [9] and temperature rise. High temperature leads thermal stress particularly on pregnant and lactating cows [17]. The breeding cattle may have poor growth so the commercial purpose may not be feasible to meet. 
Because the ecological conditions of the ex-mining area are different from natural conditions, it is necessary to study the feasibility and/or the opportunity of ICF development. As a preliminary study, this project aims to review the possibility of cattle farm development on ex-mining area in terms of the birth rate and weight gain of cattle.

\section{Material and Methods}

\subsection{Study Area}

This study was conducted in PT Berau Coal, East Kalimantan Province, Indonesia. PT Berau Coal has 4 sites namely Lati, Binungan, Sambarata and Gurimbang. Based on the formation and characteristics of coal seams, open pit is applied using a combination of hydraulic excavator equipment (backhoe and shovel), bulldozer and dump truck. The in-situ coal is classified as sub-bituminous and the coal production is classified as thermal coal with ash and sulphur content suitable for coal-fired power plants.

As a mandatory to rehabilitate the ex-mined land, PT Berau Coal has designed to conduct mine reclamation in some zones such as forestry, plantation and cattle farm. In the cattle farm planning, PT Berau Coal implements integrated concept between re-vegetation program as source of forage and livestock called Integrated Cattle Farm (ICF). The ICF was initiated in 2011 on Binungan Site and in 2018 in Lati Site for mine closure precondition purpose. The first ICF in Binungan breeds Bali cattle (Bos javanicus), the Donggala cattle (originated from Bos indicus) and the Brahman cross cattle (Bos indicus) while the newest ICF in Lati only breeds Brahman cross. The ICF has a total of 5 ha for livestock facility and 191 ha for grazing area which consists of Pennisetum sp., Brachiaria sp. and Leguminosa Cover Crop (LCC) as the forage and also re-vegetation plants.

\subsection{Data and Methods}

The cattle population and birth rate data were taken from ICF in Binungan which bred the Bali cattle (Bos javanicus), the Donggala cattle (originated from Bos indicus) and the Brahman cross cattle (Bos indicus). The data was taken from the beginning of breeding in 2013 to 2019.

The weight gain data was only taken from ICF in Lati which only bred the Brahman cross cattle. The data was taken from September 2018 to October 2019 due to the new facility in Lati. There were 3 bulls (male cattle) and 10 cows (female cattle) which the initial age was 18 to 24 months. The result then was analysed by comparing with some previous literature from commercial cattle farm.

Analysis of the demography data was taken from the report in 2007 when the addendum of environmental impact assessment (EIA) document was approved. This analysis was used to understand the characteristic of surrounding community in Binungan and Lati.

\section{Results and Discussion}

The local livelihood in the nearest sub-district in Binungan and Lati Site were mostly employed in the agriculture (70\%) which consists of food crop agriculture, plantation, animal husbandry, forestry and fishery [16]. Development of ICF was planned on the mine closure document which was adjusted with the local condition. ICF was arranged in the "Interest Zone" which adopted silvopasture concept. The concept integrates the farming, plantation and animal husbandry on ex-mining land. As preparation of mine closure, PT Berau Coal conducted some trials and experiments to meet favourable result.

\subsection{Birth Rate}

The birth rate were taken from three species in Binungan: Bali cattle, Donggala cattle and Brahman cross cattle. In general, the Bali cattle had 75 cows which was the most total number among all. The Brahman cattle had 13 cows while the Donggala cattle had 6 cows (Fig. 1).

The Donggala cattle had the highest mean birth rate (94\%) among all cattle. The mean birth rate of the Brahman cross cattle was $65 \%$ and the Bali cattle was $42 \%$. Due to the data history and site observation, the Donggala cattle 
were the most resistance to the disease and can ingest many kinds of feed. The Donggala cattle had heavier body weight and tended to have earlier first mate period [8].

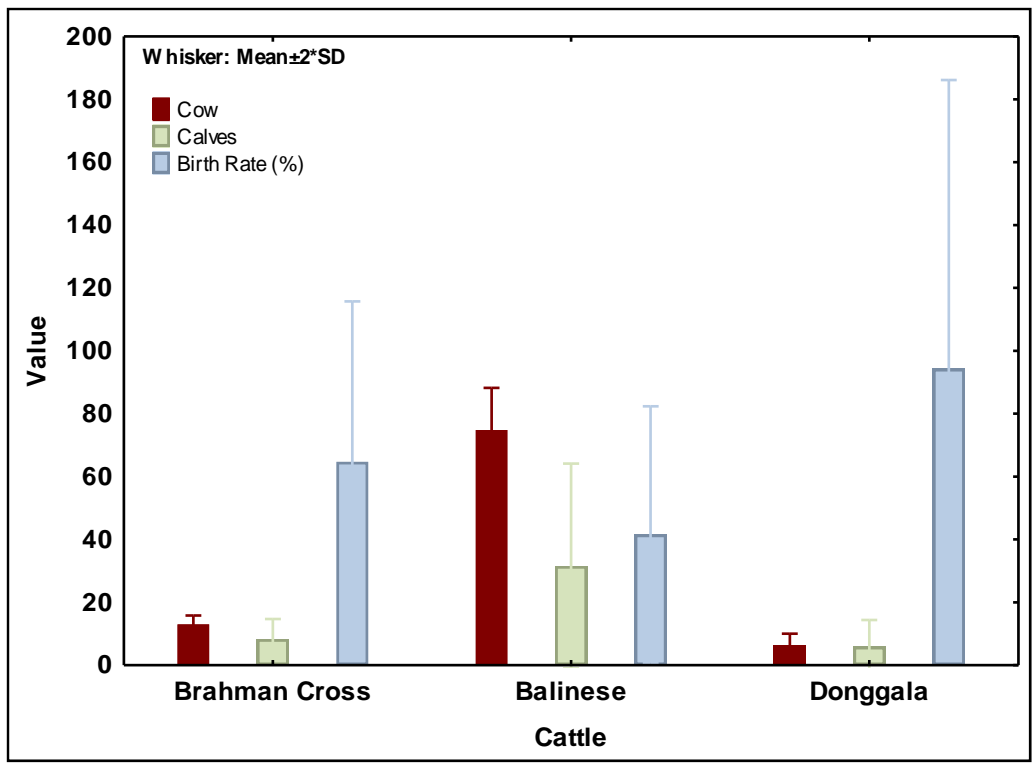

Fig. 1 The birth rate of cattle in Integrated Cattle Farm of PT Berau Coal.

Sufficient nutrition mad the female cattle gain the body weight faster and produce adequate milk for the calves. Moreover from site observation, both calves of the Bali cattle and the Brahman cross cattle were vulnerable to death because the lack of milk. The cows may suffer thermal heat which was tended to occur in lactating cows [17].

\subsection{Weight Gain}

The developed facility in Lati was part of lesson learned in Binungan which began in 2018 with only Brahman Cross cattle in the farm. From September 2018 to February 2019, intensive farming was adopted. In the intensive farming, the feed was given in the cowshed (without grazing). The weight measurement was applied to 3 male and 10 female cattle because sex was one factor which may influence the feed response beside species, age, health, and exposure [18].

In general, the male body weight increased during the study with the highest mean weight gain on male cattle occurred in March 2019 (0.34 kg/day) and the drop occurred in September 2019 (-0.20 kg/day) (Fig. 2). Therefore, there was also decreasing body weight during November 2018-January 2019. The decreased on weight may be affected by the weather variability conditions such as temperature and humidity [18]. The local temperature on ex-mining area was tended to be higher because it was an open area. The mean of female body weight had maximum increasing in September 2018 (0.53 $\mathrm{kg}$ /day) while the drop occurred in September $2019(-0.34 \mathrm{~kg} /$ day $)$. The fluctuation in weight may occur because of pregnancy and parturition.

The Fig.2 also shows that when weight gain was compared to the sex (male and female), changes in female body weight was more varied each month. This may occur not only due to the pregnancy and parturition, but also stress from high temperature [17]. The high temperature in the ICF was due to the selected form of mine reclamation which was an open area and planted with grass as feed. 


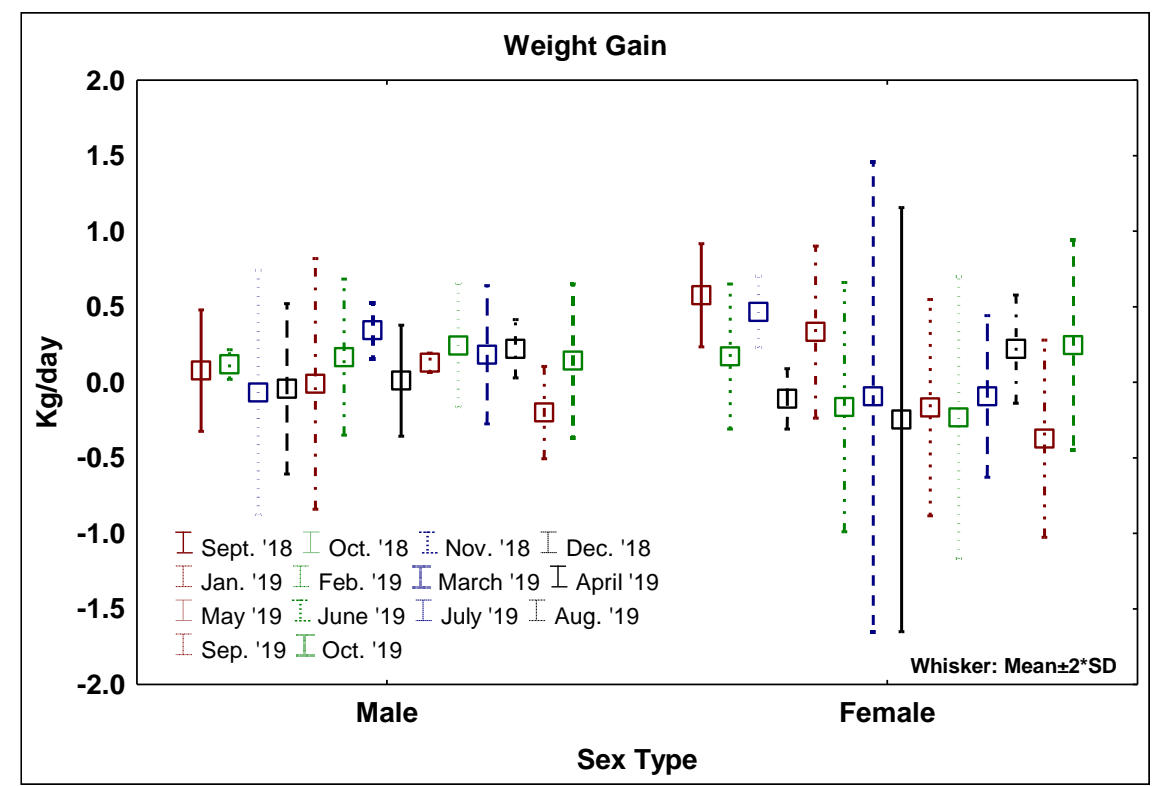

Fig. 2 The weight gain of male and female cattle in Lati.

In general, the highest weight gain of overall cattle occurred in September 2018 (0.43 kg/day) (Fig. 3) and the drop occurred in September 2019. Decrease in overall weight data may be influenced by the number of female cattle samples. During the study, the temperature was increasing above the mean temperature. The cattle may suffer the heat stress from high temperature [17]. Moreover, the small drop occurred in February 2019 because of new additional feed (silage) adaptation. The silage mostly was given to improve beef cattle weight [4].

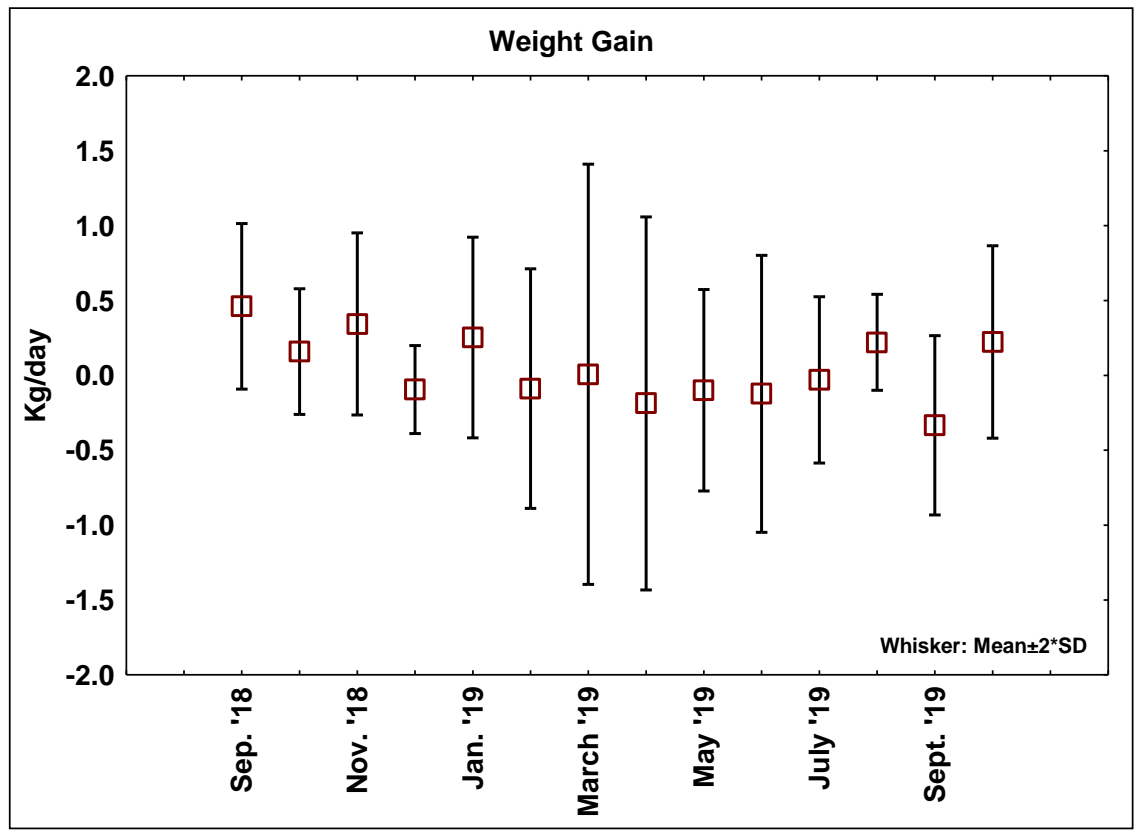

Fig. 3 The overall weight gain cattle in Lati. 
The farming system in Lati was combined due to the trial. During the six-month-experiment, the intensive farming (without grazing) was used to the cattle. During this time, mean male cattle weight $(0.04 \mathrm{~kg} /$ day) was smaller than female cattle $(0.19 \mathrm{~kg} /$ day). The female cattle may feed more in the cowshed (Fig. 4), besides some of them were in pregnancy condition.

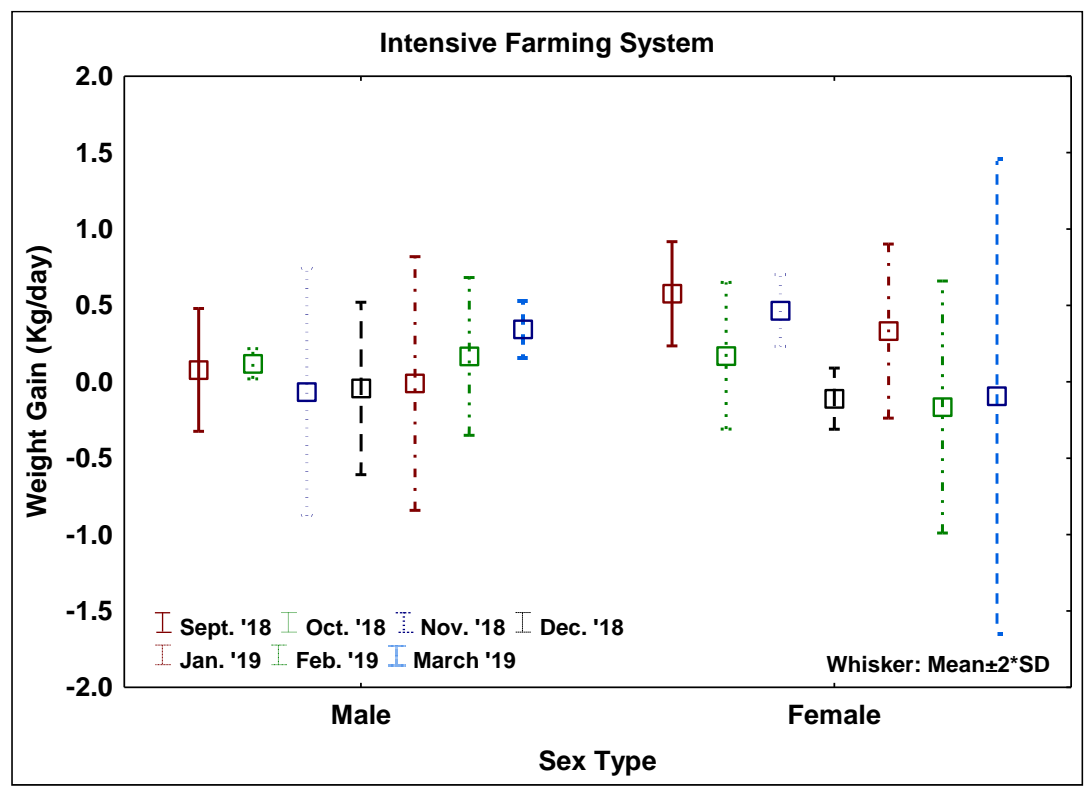

Fig.4 The weight gain based on sex type during the intensive farming.

The mean of overall weight gain was only $0.16 \mathrm{~kg} /$ day (Fig. 5). The result was below the mean of daily Brahman cross cattle weight gain $(1 \mathrm{~kg} / \mathrm{day})$ in the commercial cattle farm [2], [1]. It may occur because of the weather condition, feed quantity (feeding plan was out of commercial consideration) and the high number of female cattle of the samples.

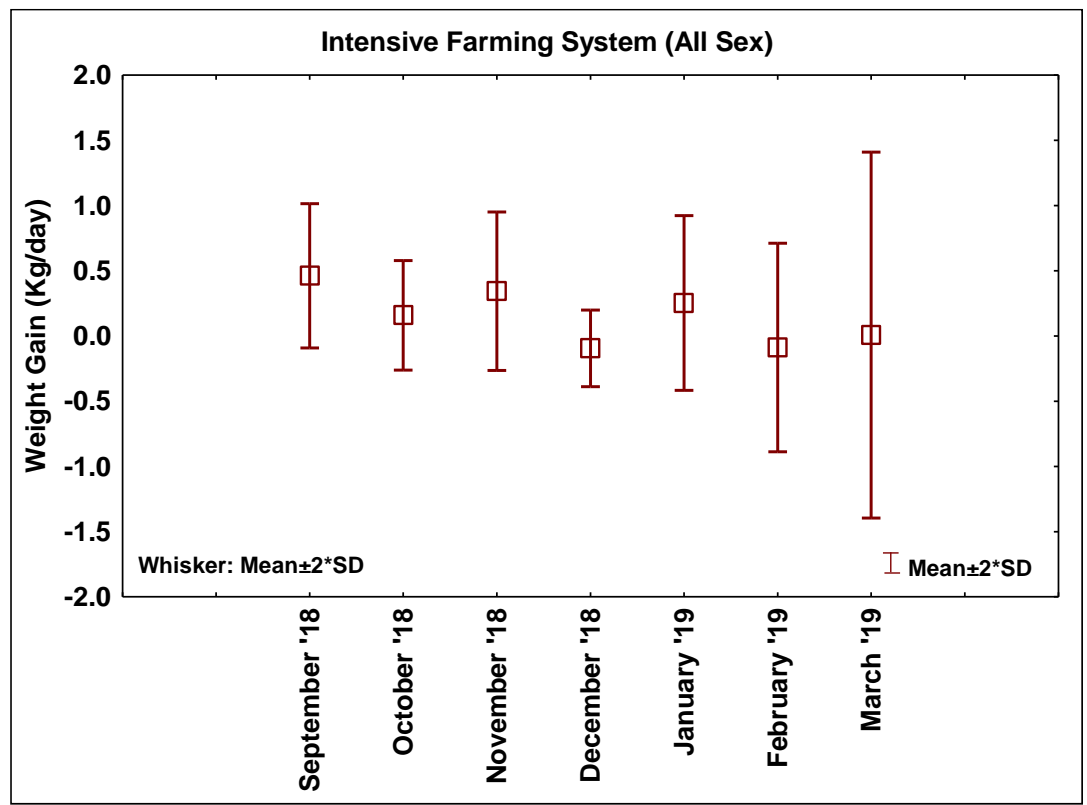

Fig.5 The overall weight gain during the intensive farming. 
To improve the performance, the ICF made the decision to change the farming system to semi-intensive in during March to October 2019. In the semi-intensive farming, the cattle were pasturing on the grazing area (ex-mining land). Pennisetum sp. and Brachiaria sp. were planted as the re-vegetation plant and forage. During the study, mean of male cattle weight $(0.13 \mathrm{~kg} /$ day $)$ was higher than female cattle $(-0.07 \mathrm{~kg} /$ day $)$ (Fig. 6). During pregnancy, female cattle experienced stress and may feed less than male cattle in the grazing area.

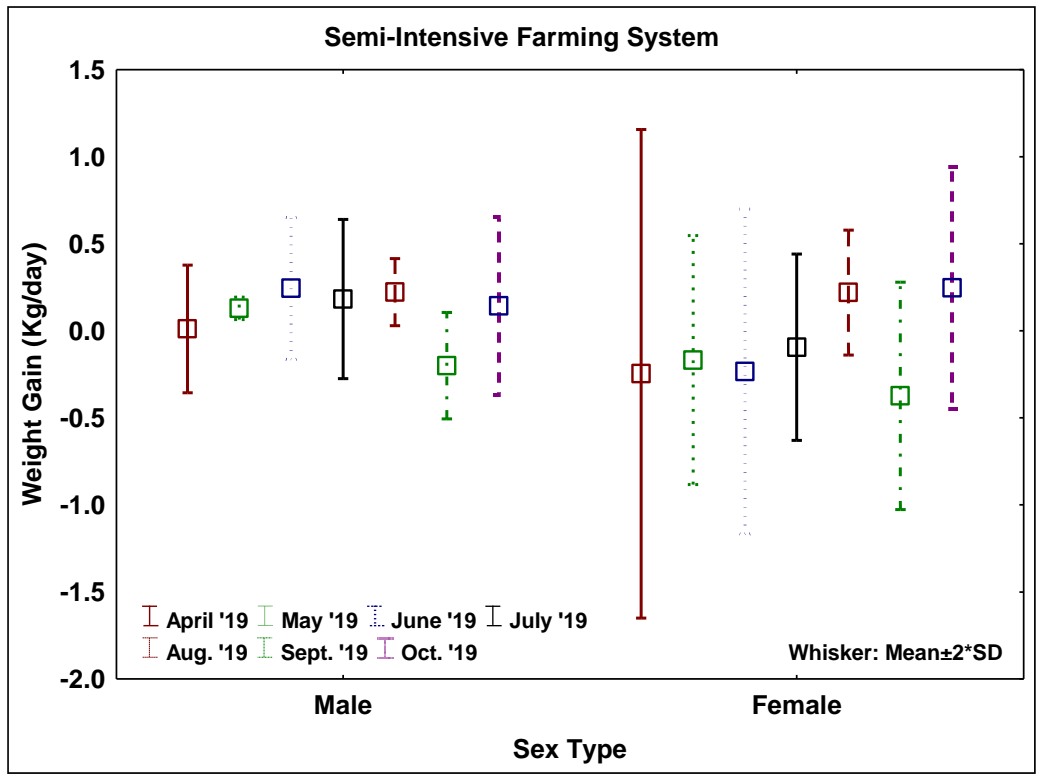

Fig.6 The weight gain based on sex type during the semi-intensive farming.

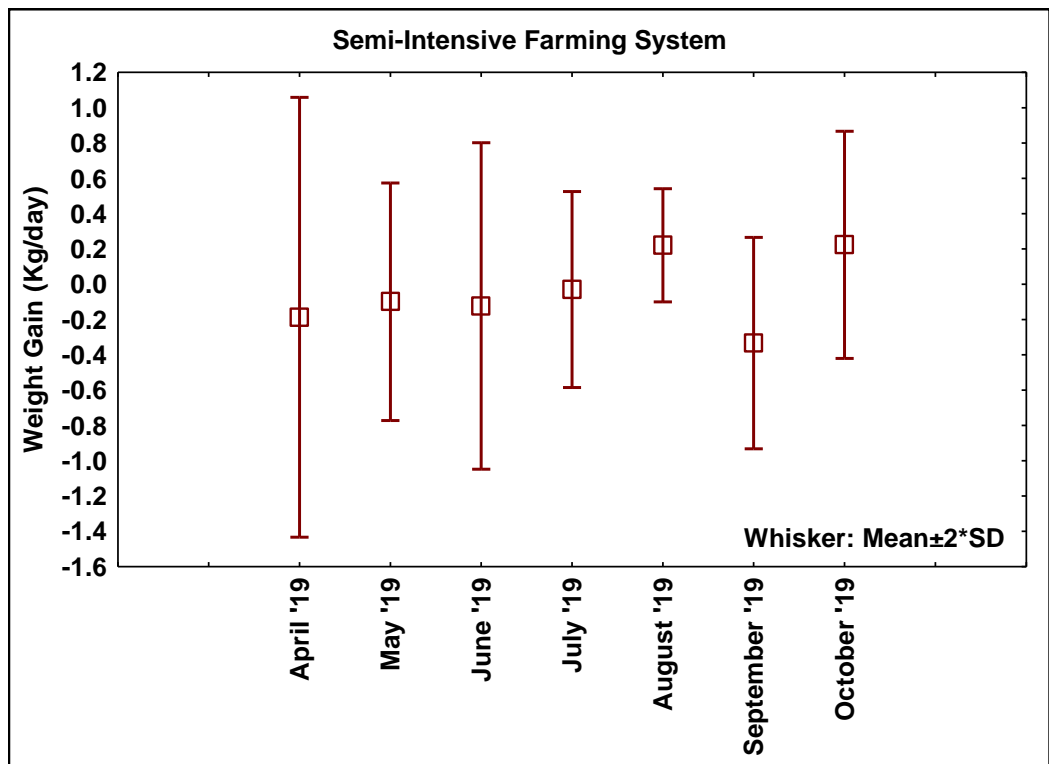

Fig.7 The overall weight gain during the semi-intensive farming.

The overall weight gain was fluctuating (Fig. 7). The highest weight gain of overall cattle occurred in August and October 2019 (0.22 kg/day) while the lowest drop occurred in September 2019 (-0.33 kg/day). The mean of overall 
weight gain was influenced by the drop on female weight $(-0.03 \mathrm{~kg} / \mathrm{day})$. The weight drop in the semi-intensive farming was similar with the intensive farming (pregnancy and samples influences). The grazing area was the ex-mining land since the local temperature may rise due to the open-area. The local temperature on grazing area may be higher than the initial temperature of forest as its initial land use [9]. High temperature also influenced the milk production and potentially caused frustration [12] since during this period, the female cattle were in the parturition and lactating phases.

From the previous study, the beef cattle industry in the tropical pasture requires strategy due to the profit. The additional of supplement and feeding has to take in order to achieve the live weight gain and market [6]. Periodical wetting with sprinkles and shade building are also listed to the heat management [18]. The additional aeration is also advised to get over 9-10\% weight gain in grazing system [7]. However, the effect of weight loss may lead to profit depression in commercial livestock industry [15] since the ICF is aimed to support community livelihood in mine closure.

\section{Conclusion}

The development of the ICF on ex-coal mining land in PT Berau Coal is based on the initial livelihood before the mining. The Donggala cattle had the highest birth rate due to the resistance ability to the disease and nutrition intake which led to the weight gain and mating period. In the semi-intensive farming, female cattle were more vulnerable to the thermal stress on pasture area whereas the male cattle showed greater weight gain than in intensive farming. However, due to the tropical condition, heat management is essential such as planning of supplement addition, feed arrangement, shade building establishment and wetting facility construction. The ICF requires more studies and experience in order to prepare mine closure program. Furthermore, the ICF is not only centre of community empowerment but also independent in order to meet the beef demand in local area.

\section{Acknowledgements}

My sincere thanks to Mr. Sri Rahajo, M.Eng.Sc. as Director of Engineering and Environment Mineral and Coal, Ministry of Energy and Mineral Resources and PT Berau Coal who have been supported us during this study.

\section{References}

[1] A. C. Pitono, H. Nugroho, Kuswati, T. Susilawati, "Performan sapi Brahman cross steer warna merah dan putih pada fase finisher," undergraduate thesis, Dept. Animal Husbandry, Malang: Universitas Brawijaya.

[2] A. Firdausi, T. Susilawati, M. Nasich, Kuswati, "Pertambahan bobot badan harian sapi Brahman cross pada bobot badan dan frame size yang berbeda," Jurnal Ternak Tropika, vol. 13, no.1, pp. 48-62, 2012.

[3] A. I. Dariah, A. Abdurachman, D, Subardja, "Reklamasi lahan eks-penambangan untuk perluasan areal pertanian," Jurnal Sumberdaya Lahan, vol. 4, no. 1, Juli 2010.

[4] A. Nurhayu, and M. Sariubang, "Pengaruh pemberian silase jerami jagung dan konsentrat pakan murah terhadap kondisi tubuh induk sapi potong di Kabupaten Pinrang Sulawesi Selatan," Prosiding Seminar Nasional Inovasi Teknologi Pertanian, Banjarbaru, 2016, pp. 1220-1226.

[5] A. S. Syarif and T. Hatori, "Corporate social responsibility for regional sustainability after mine closure: a case study of mining company in Indonesia," IOP Conf. Ser.: Earth Environ. Sci. 2nd Transdisciplinary Research on Environmental Problems in Southeast Asia, Bandung, 2017, vol.71.

[6] D. P. Poppi, S. P. Quigley, T. A. C. C. da Silva, S. R. McLennan, "Challenges of beef cattle production from tropical pastures," Brazilian Journal of Animal Science, 2018.

[7] H. A. Lardner, B. D. Kirychuk, L. Braul, W. D. Willms, J. Yarotski, "The effect of water quality on cattle performance on pasture," Australian Journal of Agricultural Research, vol. 56, no.1, pp. 97-104, 2005.

[8] I. Wumbu, B. Sundu, R. Dien, Najamudin, Miradjuddin, "Identification of reproductive activity of Donggala cattle at post puberty and post-partum periods," Journal of Biology, Agriculture and Healthcare, vol.9, no.6, pp. 32-35, 2019.

[9] J. D. Wickham, K. H. Riitters, T. G. Wade, M. Coan, C. Homer, "The effect of Appalachian mountaintop mining on interior forest," Landscape Ecol,vol. 22, pp. 179-187, 2007. 
[10] J. Kretschmann, A B Efremenkov, A A Khoreshok, "From Mining to Post-Mining: The sustainable development strategy of the German hard coal mining industry," IOP Conf. Ser.: Earth Environ. Sci. Ecology and safety in the technosphere: current problems and solutions, Yurga, 2017, vol.50.

[11] Jiuhardi, "Kajian tentang impor daging sapi di Indonesia," Forum Ekonomi, vol.17, no,2, pp. 75-91, 2016.

[12] L. Polsky and M. A.G.von Keyserlingk, "Invited review: Effects of heat stress on dairy cattle welfare," Journal of Dairy Science, vol. 100, issue 11, pp. 8645-8657, 2017.

[13] M. A. Ashraf, M. J. Maah, I. Yusoff, "Heavy metals accumulation in plants growing in ex tin mining catchment," Int. J. Environ. Sci. Tech., vol. 8, no. 2, pp. 401-416, 2011.

[14] Ministry of National Development Planning, Studi identifikasi ketahanan pangan \& preferensi konsumen terhadap konsumsi bahan pangan, Jakarta: Ministry of National Development Planning, 2015.

[15] N. R. St-Pierre, B. Cobanov, G. Schnitkey, "Economic losses from heat stress by US livestock industries." J. Dairy Sci, vol. 86, (E. Suppl.), pp. E52-E77, 2003.

[16] PT Berau Coal, “Analisis Dampak Lingkungan Hidup,” Tanjung Redep: PT Berau Coal, 2007.

[17] R. J. Collier, S. G. Doegler, H.H. Head, W. W. Thatcher, C. J. Wilcox, "Effects of heat stress during pregnancy on maternal hormone concentrations, calf birth weight and postpartum milk yield of Holstein cows," Journal of Animal Science, vol. 54, no. 2, pp. 309-319, 1982.

[18] T. M. Brown-Brandl, "Understanding heat stress in beef cattle," Brazilian Journal of Animal Science, pp. 1-9, 2018. 